Огляди літератури, оригінальні дослідження, погляд на проблему, ювілеї УДК 616.248-036.2:614.71:001.82(477.74)«2006/2016»

DOI 10.11603/1811-2471.2018.v0.i2.8636

\title{
АНАЛІЗ ПОШИРЕНОСТІ І ЗАХВОРЮВАНОСТІ НА БРОНХІАЛЬНУ АСТМУ ТА СТАНУ АТМОСФЕРНОГО ПОВІТРЯ В ОДЕСЬКОМУ РЕГІОНІ ПРОТЯГОМ 2006-2016 РОКІВ
}

\author{
๑О. І. Сандул', В. І. Величко', Г. О. Данильчук', І. О. Брашко² \\ Одеський начіональний медичний університет ${ }^{1}$ \\ Департамент охорони здоров'я Одеської обласної державної адміністрації
}

РЕЗЮМЕ. Метою нашого дослідження було провести аналіз поширеності та захворюваності на бронхіальну астму серед дорослого населення в Одеському регіоні протягом 2006-2016 рр. та оцінити епідеміологічну ситуацію по співвідношенню до техногенного навантаження атмосферного повітря основними промисловими забруднювачами.

Матеріал і методи. Проведено ретроспективний аналіз звітної документації Департаменту охорони здоров'я Одеської обласної державної адміністрації щодо поширеності бронхіальної астми серед дорослого населення Одеського регіону за період з 2006 по 2016 рік. Також були проаналізовані дані річних звітів Міністерства екології та природних ресурсів України щодо стану навколишнього природного середовища за 2010-2016 роки та проведений аналіз техногенного навантаження атмосферного повітря основними промисловими забруднювачами в Одеському регіоні за цей період. Рівні показників поширеності та захворюваності на бронхіальну астму співвідносяться з динамікою обсягів техногенного забруднення атмосферного повітря.

Результати. За проаналізований період в Одеському регіоні показники поширеності та захворюваності на бронхіальну астму серед дорослого населення значно перевищили середні показники по Україні. При цьому в атмосферному повітрі відмічалися перевищення гранично допустимих концентрацій ряду специфічних техногенних забруднювачів, здатних чинити негативний вплив на стан дихальної системи та сприяти розвитку бронхіальної астми.

Серед найнебезпечніших забруднювачів атмосферного повітря були такі шкідливі речовини як формальдегід, фенол, сажа та сірководень, концентрації яких в Одеському регіоні впродовж багатьох років перевищують гранично допустимі. Це підтверджує також факт того, що рівень поширеності та захворюваності на бронхіальну астму $\epsilon$ вищим у містах регіону, де зосереджені важливі промислові об'єкти, ніж у сільській місцевості. Рівні показників захворюваності на бронхіальну астму співвідносяться з динамікою обсягів забруднення атмосферного повітря. Так, збільшення об'ємів викидів техногенних забруднювачів збігалося у часі зі зростанням захворюваності на бронхіальну астму у регіоні.

Висновки. Простежується чіткий взаємозв'язок між динамікою захворюваності на бронхіальну астму та рівнем техногенного навантаження атмосферного повітря основними промисловими забруднювачами, оскільки піки забруднення та захворюваності збігаються в часі.

КлючОВІ СлОВА: бронхіальна астма; поширеність; захворюваність; техногенні забрудники; атмосферне повітря.

Вступ. Впродовж багатьох років бронхіальна астма (БА), як рецидивуюче хронічне захворювання, залишається надзвичайно актуальною проблемою галузі охорони здоров'я України. За останні роки поширеність БА серед дорослого населення значно зросла - майже на $44,2 \%$ у порівнянні 3 1991 роком. Проте існує припущення, що дані офіційної статистики не відображають дійсної картини поширеності БА в Україні та свідчать про значний рівень ії гіподіагностики $[1,2]$. Підтвердженням цього слугує загальна захворюваність на БА в Україні, яка, за офіційною статистикою, знаходиться на рівні $0,48 \%$, тоді як Всесвітня організація охорони здоров'я повідомляє про середню поширеність у світі на рівні $5 \%$, тобто на цілий порядок вище [1]. 3 одного боку, це пояснюється недосконалістю медичної статистичної звітності, з іншого невисокою настороженістю лікарів загальної практики - сімейної медицини щодо цього захворювання та їх неналежною поінформованістю про діагностичні критерії БА, недостатністю знань щодо диференційної діагностики БА та хронічної обструктивної хвороби легень [2].

Астма належить до індикаторних захворювань, які певною мірою можуть бути залежними від стану навколишнього середовища, зокрема від забрудненості повітря хімічними та біологічними полютантами, які належать до екзогенних факторів ризику розвитку цього захворювання. Зростанню забрудненості атмосферного повітря сприяють прогресивна урбанізація, недостатня модернізація технологічного обладнання підприємств, яка повинна була 6 сприяти зменшенню викидів полютантів у зовнішнє середовище, збільшення промислових потужностей, які прямо або опосередковано здатні впливати на поширеність та захворюваність БА [3]. Відомо, що Одеська область - це регіон, який, завдяки вигідному географічному розташуванню, виконує роль важливого транспортно-розподільчого коридору, та- 
Огляди літератури, оригінальні дослідження, погляд на проблему, ювілеї

кож характеризується високим рівнем розвитку сільського господарства та промисловості. За даними наглядових служ6, понад 3 тисячі підприємств у нашому регіоні впливають на стан атмосферного повітря. Незважаючи на те, що Одеський регіон - це курортна зона на березі Чорного моря, він має високе антигенне навантаження, яке постійно впливає на імунну систему людини та здатне індукувати алергічне запалення дихальних шляхів внаслідок поєднаного впливу різноманітних техногенних забруднювачів $[3,4]$.

Мета - провести аналіз поширеності та захворюваності на бронхіальну астму серед дорослого населення в Одеському регіоні протягом 20062016 рр. та оцінити епідеміологічну ситуацію у співвідношенні з техногенним навантаженням атмосферного повітря основними промисловими забруднювачами.

Матеріал і методи дослідження. Проведено ретроспективний аналіз звітної документації Департаменту охорони здоров'я Одеської облдержадміністрації щодо поширеності БА серед дорослого населення Одеської області за період з 2006 по 2016 рік. Була проведена вибірка показників поширеності та захворюваності на БА, рівня диспансеризації, кількості пролікованих пацієнтів з БА у стаціонарах протягом 10 років.

Також проаналізовані річні звіти Міністерства екології та природних ресурсів України щодо стану навколишнього природного середовища в Україні за 2010-2016 рр. та проведено аналіз техногенного навантаження атмосферного повітря основними промисловими забруднювачами саме в Одеському регіоні за цей період. Статистичний аналіз проводили за допомогою програми Microsoft Excel 2013 для Windows.

Результати й обговорення. Ретроспективний аналіз звітної медичної документації Департаменту охорони здоров'я Одеської облдержадміністрації свідчить, що поширеність БА (шифр МКX J45) серед дорослого населення у регіоні $€$ досить високою. Так, поширеність цієї патології в Одеській області в 2016 році склала 562,3 випадку на 100 тис. населення, а захворюваність - 25,4 на 100 тис. Згідно з даними НАМН України та Центру медичної статистики МОЗ України, середній показник поширеності БА по країні за аналогічний період був значно нижчим та становив 491,9 випадків на 100 тис., а середньостатистичний показник захворюваності, відповідно, - 22,7 на 100 тис. [5].

Таким чином, можна зробити висновок, що загальна та первинна захворюваність на БА в Одеському регіоні значно перевищує середні показники по Україні.

При аналізі регіональної поширеності БА по Україні виявилося, що в 2016 році Одеський регі- он зайняв 6 місце за захворюваністю та 13 за поширеністю серед 24 областей України та м. Києва [5]. В той же час, за загальним рівнем викидів шкідливих речовин у атмосферу в 2014 році Одеський регіон зайняв 15 місце з показником в 23,2 тис. т викидів за рік [4]. Цей факт розходиться з наявністю такої високої захворюваності та поширеності на БА в регіоні та свідчить про те, що ці показники не знаходяться у прямій залежності від рівня загального забруднення, отже, потрібно виявити інші чинники, які $є$ детермінуючими. Ця розбіжність пояснюється, на наш погляд, тим, що в Одеському регіоні забруднення обумовлено не загальними обсягами неспецифічних забруднювачів, а саме високим вмістом специфічних шкідливих речовин, таких як формальдегід, фенол, сажа, сірководень, оксид вуглецю. Саме ці шкідливі речовини чинять негативний вплив на стан дихальних шляхів та здатні провокувати напади БА. На жаль, за середньорічним вмістом цих забруднювачів у повітрі Одеса посідає одне з перших місць в Україні. Підтвердженням цього $\epsilon$ також індекс забрудненості атмосфери (IЗА). Наприклад, в 2016 році Одеса посіла 3 місце в Україні за значенням цього показника $[4,6,7]$.

Проведений нами аналіз виявив певні закономірності у розподілі значень показника поширеності БА, який відображає загальну кількість захворювань (рис. 1).

За період з 2006 по 2012 рік спостерігалося збільшення поширеності БА. За вказані роки загальна кількість зареєстрованих захворювань на БА серед населення Одеської області збільшилась на 78,8 тис., тобто на 13 \%. При цьому слід зазначити, що протягом 2006-2011 років спостерігалося поступове збільшення кількості хворих на БА, в середньому на 7,1 тис. осіб, тобто на 1,17 \% щорічно. Вагоме зростання показника поширеності БА припало саме на період 2011-2012 роки та склало 36,2 тис. випадків, що перевищило показники попередніх років майже у 5 разів. У подальшому спостерігалася протилежна тенденція щодо зниження поширеності, починаючи з 2013 по 2015 рік в середньому цей показник щорічно зменшувався майже на 11,06 тис. зареєстрованих захворювань, тобто на 1,82 \%, та вийшов на рівень 2011 року.

Слід зазначити, що у містах Одеської області поширеність БА була в середньому в 1,5 раза вищою, ніж у районах сільської місцевості (рис. 2). Так, середній показник у містах склав $(671,68 \pm 36,4)$ випадків захворювання БА на 100 тис. населення, а в сільській місцевості цей показник був на рівні $(440,85 \pm 15,95)$ випадків на 100 тис. населення, що, ймовірно, можна пояснити відмінністю якісного складу повітря та його техногенного навантаження промисловими забруднювачами в містах. У цьому 
Огляди літератури, оригінальні дослідження, погляд на проблему, ювілеї

ряду виняток складає м. Южне, в якому стабільно протягом десятиріччя поширеністьБАне перевищувала 4,24 \%, більше того, спостерігалася стійка тенденція до зниження цього показника, не дивлячись на те, що саме м. Южне посідає 2 місце в структурі забрудненості повітря в Одеському регіоні. Цей фе- номен, мабуть, можна пояснити тим, що м. Южне $є$ сателітом м. Одеси, у зв'язку з чим значна частина населення обслуговується у лікувально-профілактичних закладах обласного центру, тому частково поширеність БА серед його жителів фіксується саме в статистичних показниках м. Одеси.

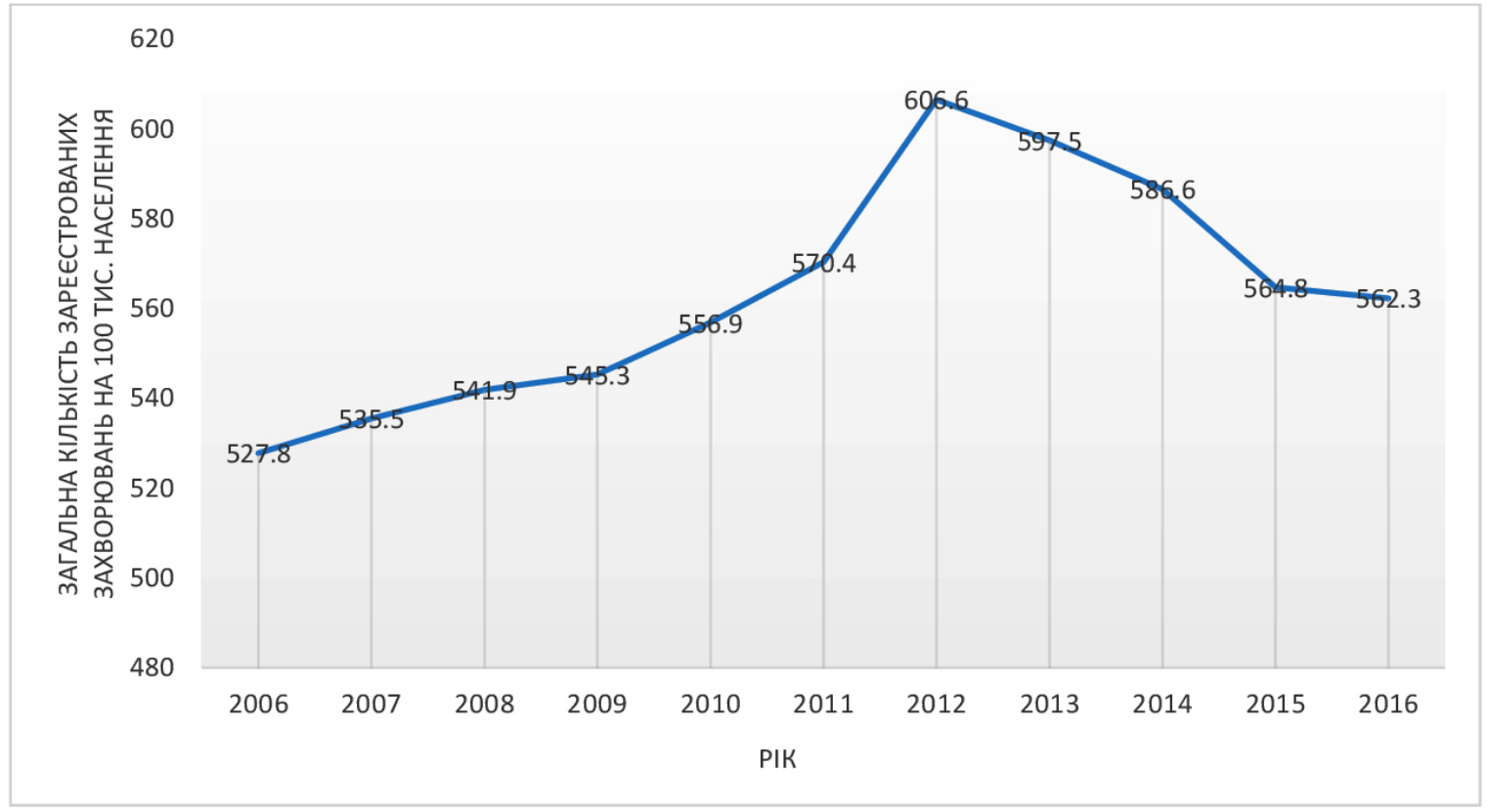

Рис. 1. Динаміка поширення бронхіальної астми серед дорослого населення Одеського регіону за 2006-2018 рр.

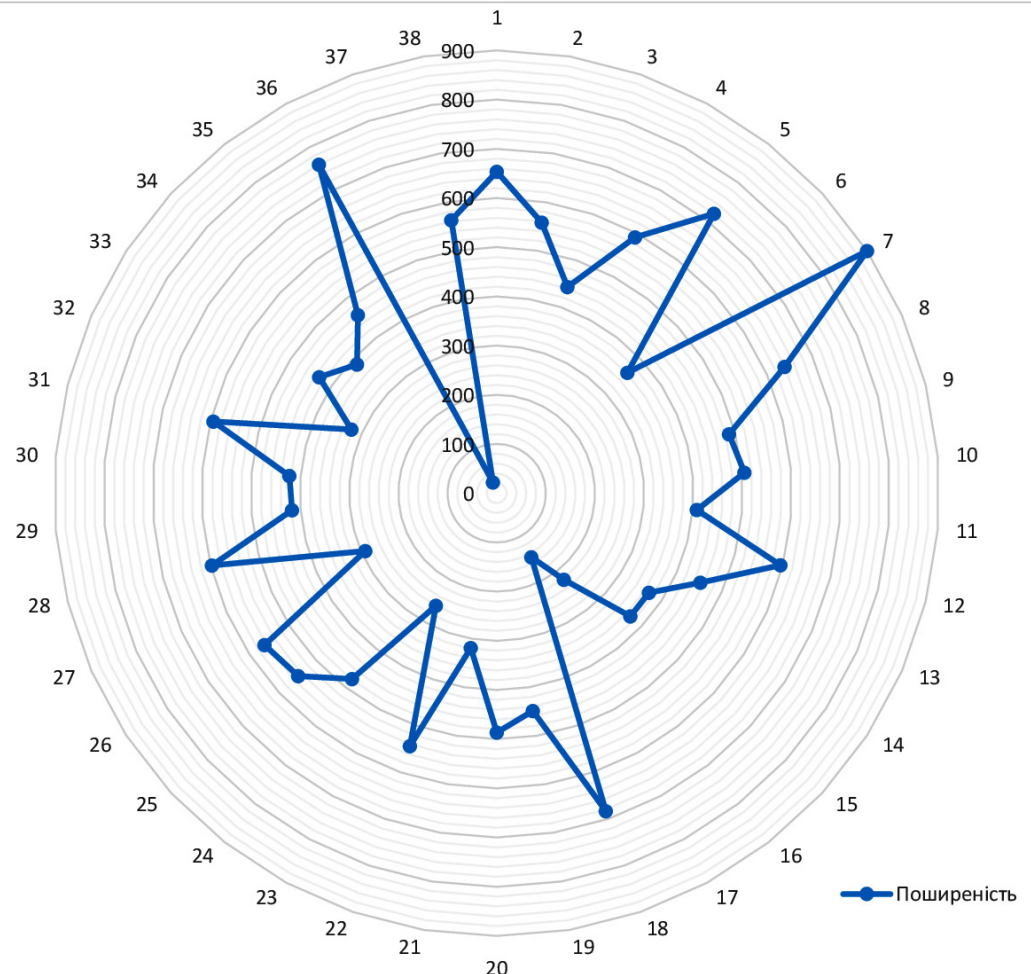

ЗАГАЛЬНА КІЛЬКІСТЬ ЗАРЕЕСТРОВАНИХ ЗАХВОРЮВАНЬНА 100 ТИС. НАСЕЛЕННЯ
1 - м. Одеса; 2 - м. Б.-Дністровський; 3 - м. Подільськ; 4 - м. Балта; 5 - м. Ізмаїл; 6 - м. Южне; 7 - м. Теплодар; 8 - міста, всього; 9 - Ананьївський район; 10 - Арцизький район; 11 - Балтський район; 12 - Біляївський район; 13 - Березівський район; 14 - Белградський район; 15 Б. Дністровський район; 16 - В. Михайлівський район; 17 - Захарівський район; 18 - Іванівський район; 19 - Ізмаїльський район; 20 - Кілійський район; 21 -Колимський район; 22 - Лиманський район; 23 - Любашівський район; 24 - Миколаївський район; 25 - Овідіопольський район 26 - Окнянський район; 27 - Подільський район; 28 - Роздільнянський район; 29 - Ренійський район; 30 - Савранський район; 31 - Саратський район; 32 - Тарутинський район; 33 - Татарбунарський район; 34 - Ширяївський район; 35 - сільські райони, всього; 36 - зведення по м. Іллічівськ; 37 - республіканські заклади, всього; 38 - усього по області.

Рис. 2. Поширеність БА серед дорослого населення у містах та районах Одеської області. 
Огляди літератури, оригінальні дослідження, погляд на проблему, ювілеї

Найвищий показник поширеності БА виявлено в містах Теплодар, Чорноморськ, Ізмаїл та Одеса. Цікаво, що для м. Теплодар, де показник поширеності БА перевищує більше ніж в 2 рази середній по регіону (904,4 випадки на 100 тис. дорослого населення), характерний мінімальний показник забрудненості атмосферного повітря. Такі різкі відмінності між поширеністю БА та якісним складом атмосферного повітря не можна пояснити, у зв'язку з відсутністю даних щодо специфічних техногенних забруднювачів атмосферного повітря м. Теплодар.

Разом з тим, слід констатувати, що у більшості сільських районів Одеської області у період з 2006 по 2016 рр. також прослідковується тенденція до зростання поширеності БА. Значний приріст спостерігали в Арцизькому, Б. Дністровському, Кілійському та Окнянському районах, де загальна кількість хворих на БА в середньому збільшилася в 1,3 раза. Найбільший приріст показника був харак- терний для Саратського району, де поширеність БА зросла в 1,7 раза. Причиною виявленого, на нашу думку, $\epsilon$ інтенсивне ведення сільськогосподарського виробництва із застосуванням різних добрив, гербіцидів тощо. Протилежну динаміку виявлено в Захарівському та Подільському районах, де за вказаний період відбулося зниження поширеності БА в 1,4 раза, а загалом середній приріст показника по сільських районах області за період 2006-2016 рр. склав 10,6 \%.

Водночас показник захворюваності у Одеському регіоні, який відображає загальну кількість виявлених нових випадків патології, загалом мав хвилеподібну тенденцію до зниження, з двома піками протягом 2007-2008 та 2012-2013 років; та двома хвилями підвищення у 2009-2019 та 2014 роках. У 2011 році відзначено його найбільше зростання, особливо порівняно з попереднім роком. Впродовж 2015-2016 років відмічають практично сталі показники (рис. 3).

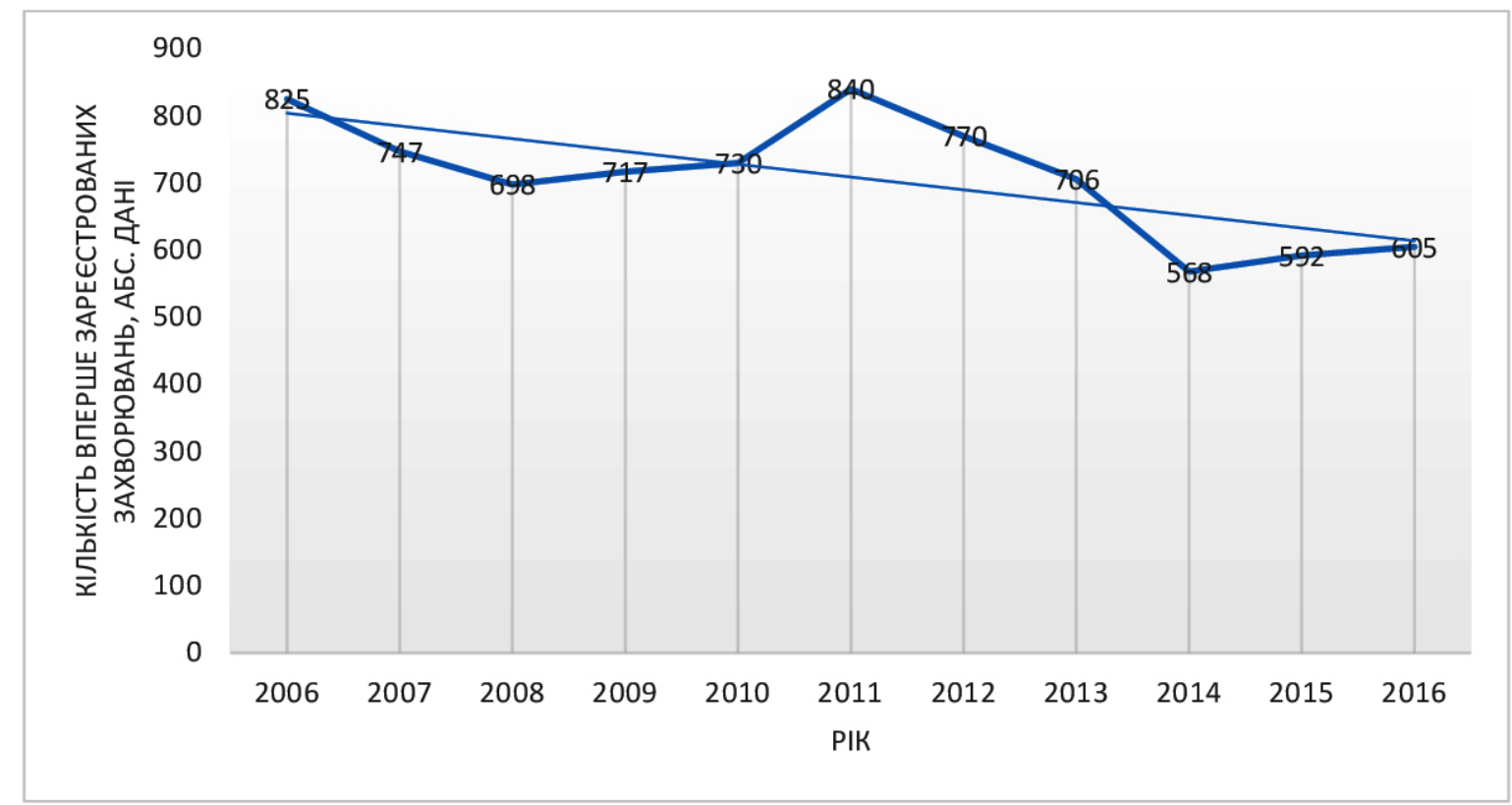

Рис. 3. Динаміка захворюваності на бронхіальну астму серед дорослого населення Одеського регіону за 2006-2016 pp.

Загалом за весь період, що аналізується, відбувся спад захворюваності по області на 26,6 \%. Протягом останніх трьох років відмічаються більш-менш сталі показники. Найбільший спад відбувся у 2014 році, коли показник захворюваності був мінімальним - 23,8 на 100 тис. населення.

Найбільше зростання захворюваності спостерігалося у Миколаївському районі, де кількість виявлених нових випадків БА за десятилітній період збільшилася майже втричі. Більше ніж удвічі цей показник зріс у Б. Дністровському, Окнянському та Саратському районах (рис. 4). Серед міст абсолют- ним лідером зі зростання захворюваності $\epsilon$ м. Южне, де в 2016 р. цей показник зріс до 98,9 випадків на 100 тис, що є більш ніж в 1,5 раза більше, порівняно з попереднім роком. Це незважаючи на те, що поширеність БА у цьому місті має стійку тенденцію до зниження. 3 іншого боку, в деяких районах області (Ананьївський, Ізмаїльський, Савранський, Тарутинський) захворюваність на БА значно знизилася, практично в 3 рази. Найбільша тенденція до зниження захворюваності спостерігається в Іванівському районі, в якому кількість вперше встановлених випадків БА зменшилася в 4,6 раза за проаналізований період. 


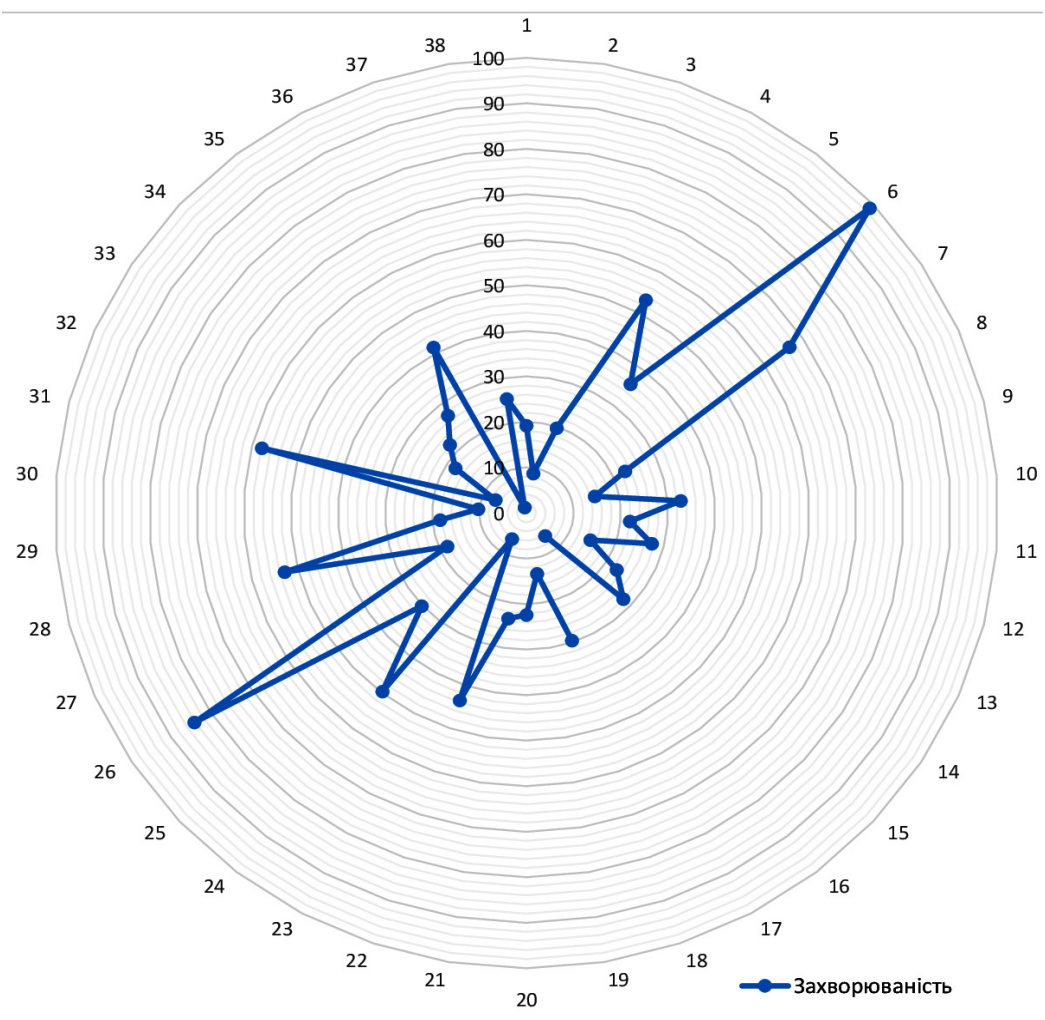

1 - м. Одеса; 2 - м. Б.-Дністровський; 3 - м. Подільськ; 4 - м. Балта; 5 - м. Ізмаїл; 6 - м. Южне; 7 - м. Теплодар; 8 - міста, всього; 9 - Ананьївський район; 10 - Арцизький район; 11 - Балтський район; 12 - Біляївський район; 13 - Березівський район; 14 - Белградський район; 15 Б. Дністровський район; 16 - В. Михайлівський район; 17 - Захарівський район; 18 - Іванівський район; 19 - Ізмаїльський район; 20 - Кілійський район; 21 - Колимський район; 22 - Лиманський 1 район; 23 -Любашівський район; 24-Миколаївський район; 25 - Овідіопольський район; 26 - Окнянський район; 27 - Подільський район; 28 - Роздільнянський район; 29 - Ренійський район; 30 - Савранський район; 31 - Саратський район; 32 - Тарутинський район; 33 - Татарбунарський район; 34 - Ширяївський район; 35 - сільські райони, всього; 36 - зведення по М. Іллічівськ; 37 - республіканські заклади, всього; 38 - усього по області.

КІЛЬКІСТЬВПЕРШЕ ЗАРЕЕСТРОВАНИХЗАХВОРЮВАНЬ, АБС. ДАНІ

Рис. 4. Захворюваність на БА серед дорослого населення у містах та районах Одеської області.

Загалом аналізуючи захворюваність на БА протягом 2006-2016 років ми виявили, що середній показник захворюваності на БА в Одеському регіоні склав $(29,75 \pm 3,78)$ на 100 тис. населення та був вищим за середній показник по Україні $(22,63 \pm 3,24)$ на 100 тис. населення за аналогічний період.

Аналізуючи рівень диспансеризації хворих на БА в Одеському регіоні потрібно констатувати, що повнота охоплення дорослого населення знаходиться на належному рівні (рис. 5). Якість диспансеризації за проаналізований період можна охарактеризувати як достатню, оскільки цей показник утримується практично постійно на рівні близько 94 \%, за винятком 2012-2014 років, коли на диспансеризації знаходилося лише близько 88 \% від загального числа хворих.

Разом з високими показниками рівня диспансеризації щорічна кількість осіб, пролікованих у стаціонарах з приводу БА, за період з 2006 по 2016 роки прогресивно зменшувалася. Так, найбільша кількість госпіталізованих до стаціонарів з причини БА була у 2006 році та знаходилася на рівні 27,3 \%, а вже в 2016 році цей показник зменшився в 1,5 раза та досяг рівня 17,3\%. Ці обставини можна пояснити підвищенням ефективності базисної терапії та досягненням астма-контролю завдяки широкому арсеналу інгаляційних анти- астматичних препаратів, які стали активно використовуватися протягом останнього десятиріччя, та достатньою обізнаністю населення щодо небулайзерної терапії.

При аналізі факторів, які здатні вплинути на стан захворюваності на БА, слід звернути увагу на характеристику атмосферного повітря навколишнього середовища та техногенні фактори, що його змінюють. За даними річних звітів Міністерства екології та природних ресурсів України, представленихунаціональнихдоповідяхпро стан навколишнього природного середовища за 2010-2016 рр., найбільші обсяги викидів забруднювальних речовин в атмосферу по Одеському регіону спричиняють енергопродукуючі підприємства - 47 \%; підприємства харчової промисловості - $7 \%$; хімічної галузі - 5 \% та підприємства, що забезпечують діяльність транспорту та зв'язку - $21 \%$. Здебільшого вони зосереджені у містах Одеса, Южне, Ізмаїл, Подільськ. Найбільшими стаціонарними забруднювачами атмосфери Одеського регіону $\epsilon$ ПАТ «Одеський припортовий завод", підприємства енергетики: ПрАТ «Газтранзит» та ПАТ «Одесагаз». Однак основний внесок у забруднення атмосферного повітря Одеської області та України належить пересувним джерелам, а саме автотранспортним засобам, які «забезпечують» 80 \% від усього забруднення, що надходить в атмосферне повітря [4]. 
Огляди літератури, оригінальні дослідження, погляд на проблему, ювілеї

Загальна кількість осіб, що перебувають під диспансерним наглядом, абсол. дані

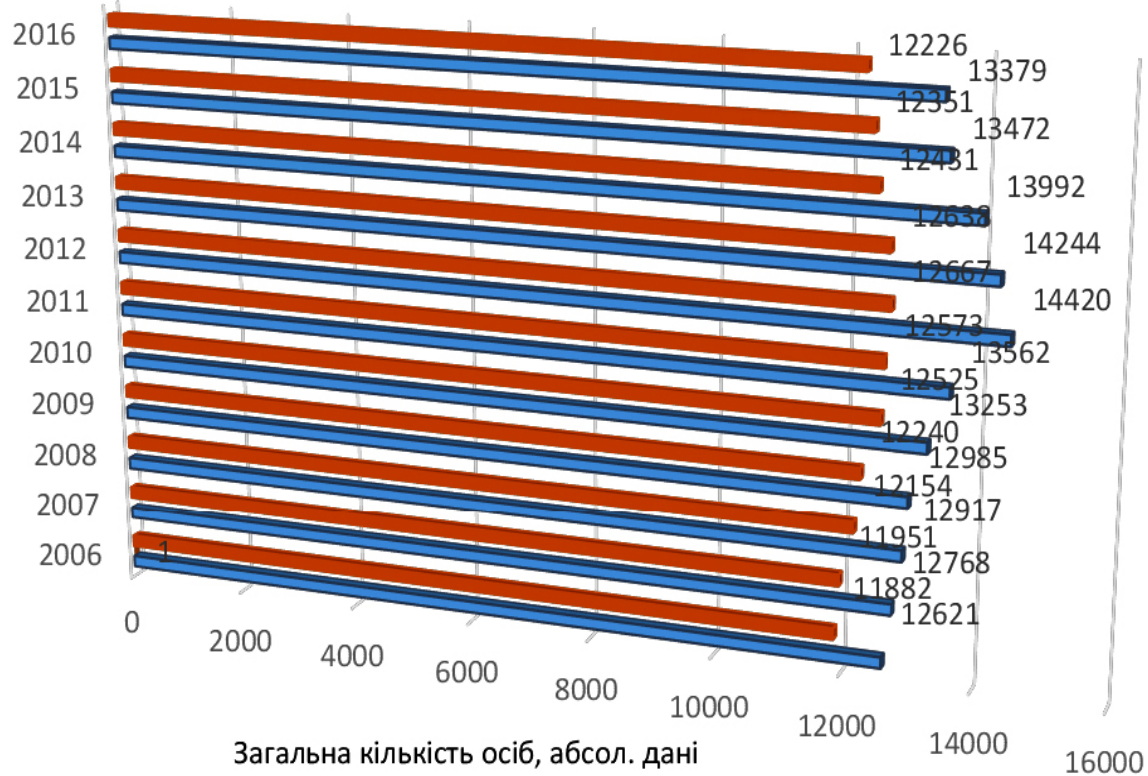

—знаходяться під диспансерним наглядом на кінець року Зареєстровано захворювань всього

Рис. 5. Рівень диспансеризації хворих на бронхіальну астму серед дорослого населення Одеського регіону за 2006-2016 pp.

За даними Міністерства екології та природних ресурсів, Одеса входить до переліку міст з перевищенням середньорічної концентрації цілого ряду речовин, які забруднюють атмосферне повітря. Лідером у цьому ряду $\epsilon$ викиди формальдегіду, які перевищували гранично допустимі концентрації (ГДК) в 4,7 раза в 2014 році та в 4 рази в 2015 році. За дослідженнями 2016 року, у 73 (6 \%) із 1217 відібраних проб атмосферного повітря в Одеському регіоні було зафіксовано перевищення ГДК шкідливих речовин, причому в кожному п'ятому випадку це був формальдегід [4].

Відомо, що формальдегід, окрім канцерогенної дії, має ще й неканцерогенні ефекти, у тому числі подразнювальний вплив на слизову оболонку дихальних шляхів, та здатний провокувати розвиток БА [7]. Yingshui Үао та співавт. у 2015 році опублікували мета-аналіз, який охопив дані 8 досліджень по всьому світі (загальна вибірка склала 718 пацієнтів), в якому оцінили взаємозв'язок між концентрацією формальдегіду та астмою. Було встановлено, що цей забруднювач $\epsilon$ детермінуючим фактором у розвитку БА [8]. Автори припускають, що формальдегід може відігравати ключову роль саме на початковій стадії астми, виконуючи роль індуктора алергічної реакції. Можливо, механізм такого впливу пов'язаний з його пошкоджувальною дією на морфофункціональну сталість клітинних мембран. Ця хімічна речовина спричиняє пригнічення антирадикального захисту, що призводить до збільшення рівня вільних радикалів, які, в свою чергу, викликають розриви клітинних мембран опасистих клітин та базофілів у дихальних шляхах. Можливо, саме це слугує пусковим механізмом розвитку БА [8].

Схожий вплив на дихальну систему чинить фенол - летюча отруйна речовина, що має сильну подразнювальну та загальнотоксичну дію. У 2016 році його середньорічний вміст у повітрі Одеси перевищував допустимі концентрації в 1,3 раза. Також Одеса є єдиним містом в Україні, де спостерігається перевищення викидів сажі, котра також належить до агентів, здатних спричинити виникнення астми, наприклад у 2016 році концентрація цього забруднювача у повітрі була у 1,2 раза вищою від ГДК [4].

Ще одним шкідливим забруднювачем $\epsilon$ сірководень - легкорозчинна отрута подразнювальної дії, що вражає переважно слизову оболонку верхніх дихальних шляхів та крупних бронхів. Максимально разова середньорічна концентрація сірководню в атмосферному повітрі м. Одеси перевищувала ГДК у 1,9 раза в 2016 році [4].

Глобальною екологічною проблемою, здатною негативно впливати на стан дихальних шляхів, $\epsilon$ кислотні дощі, які $\epsilon$ результатом промислових викидів в атмосферу діоксиду сірки та оксидів азоту. Ці сполуки, з'єднуючись з атмосферною вологою, утворюють сірчану та азотну кислоти. Ще у 80 роках минулого століття були опубліковані роботи, які підтвердили негативний вплив кислотних опадів на 
Огляди літератури, оригінальні дослідження, погляд на проблему, ювілеї респіраторну функцію у хворих на БА [9]. Для України це явище на сьогодні досить рідкісне, але, на жаль, воно досі спостерігається в Одеському регіоні. Державною гідрометеорологічною службою постійно здійснюється контроль за хімічним складом атмосферних опадів та їх кислотністю, що відображається у щорічних звітах. Так, у 2015 році з досліджених дощів загалом по країні спостерігалось 0,10\% кислих, тобто таких, рН яких нижче 5,6, при цьому більша їх частина була зафіксована саме на станціях Одеського регіону $[6,7]$. Також в Одесі спостерігався один з найбільших відсотків помірнокислих опадів - 62,34 \% (2 місце по Україні) [4].

Динаміка викидів забруднювальних речовин у атмосферне повітря тісно пов'язана з динамікою захворюваності на БА (рис. 6). Так, у 2011 р., порівняно з 2010 р., спостерігалося збільшення техногенного навантаження на атмосферне повітря в Одеському регіоні, що збігається з відповідним підвищенням захворюваності на БА. У 2015 р., порівняно із показниками 2012 р., техногенне навантаження на атмосферне повітря зменшилось в цілому по області на 39,27 тис. т. Цей факт збігається з відповідним зменшенням рівня захворюваності дорослого населення на БА з 32,4 до 24,8 на 100 тис. населення.

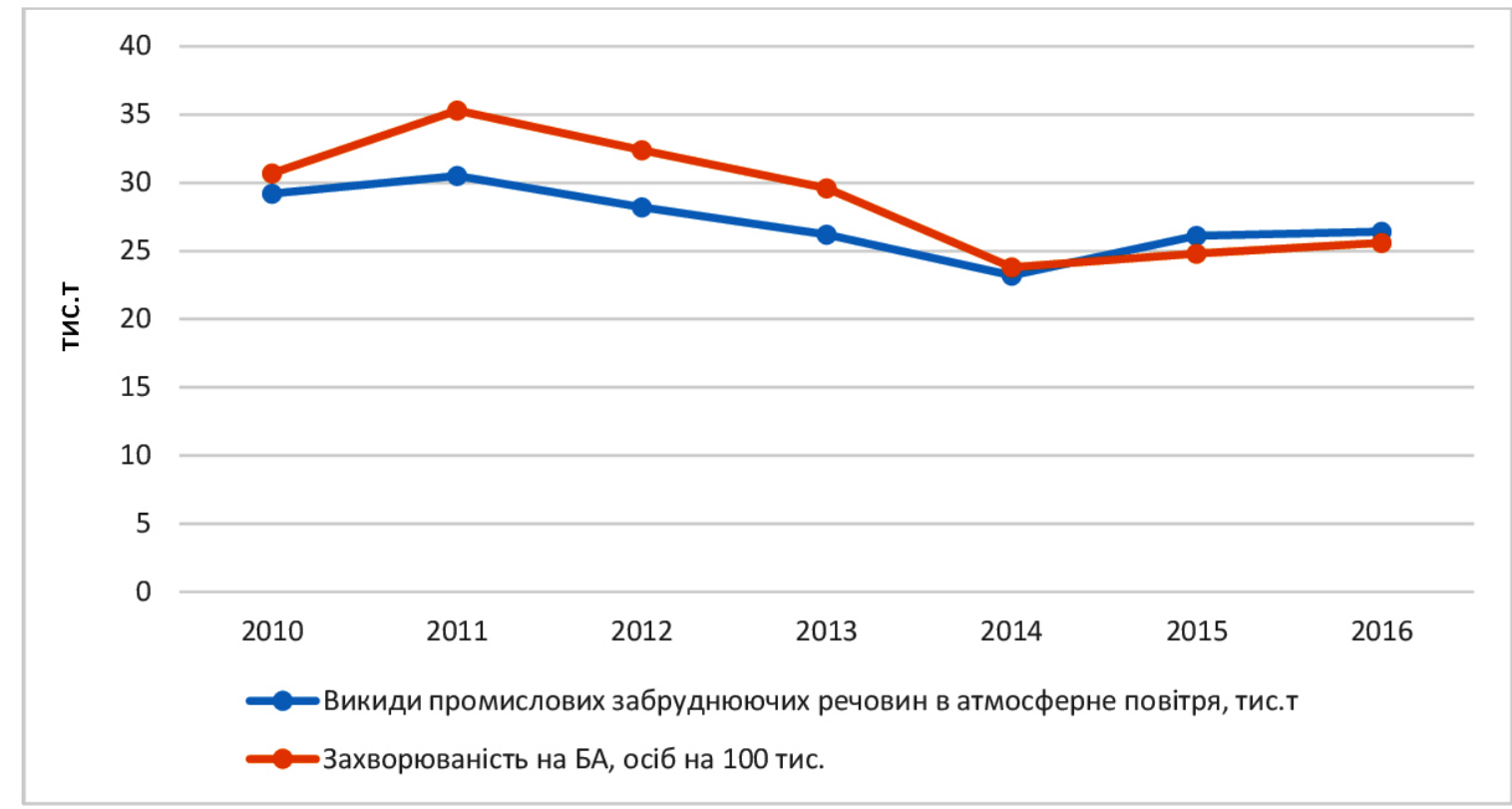

Рис. 6. Динаміка захворюваності БА та техногенного навантаження на атмосферне повітря в Одеській області.

Висновки. 1. Результати багаторічного аналізу рівнів поширеності та захворюваності на БА серед дорослого населення Одеського регіону свідчать про короткочасну стабілізацію епідемічної ситуації, яка проявляється тенденцією до незначного зменшення поширеності починаючи з 2012 року. Також простежується загальна тенденція до зниження захворюваності: кількість вперше зареєстрованих хворих у 2016 році зменшилась на 26,7 \%, порівняно з даними 2006 року.

2. Рівні поширеності та захворюваності на БА в Одеській області $\epsilon$ вищими у містах, де зосереджені важливі промислові об'єкти, ніж у сільській місцевості. У 2016 році найвищий показник поширеності спостерігався в містах Теплодар, Чорноморськ, Ізмаїл та Одеса.

3. Прослідковується тенденція до зменшення кількості госпіталізацій до стаціонарів з приводу загострень БА протягом останніх 10 років, що свідчить про покращення контролю над перебігом аст- ми, в тому числі й завдяки високому рівню охоплення населення диспансерним спостереженням та підвищенню ефективності базисної терапії.

4. Простежується чіткий взаємозв'язок між динамікою захворюваності на БА та рівнем техногенного навантаження атмосферного повітря основними промисловими забруднювачами, оскільки піки викидів забруднювальних речовин та зростання захворюваності збігаються у часі. За рівнем індексу забрудненості повітря м. Одеса протягом багатьох років займає лідируючі позиції серед міст України, що, ймовірно, сприяє високій поширеності БА в Одеському регіоні, яка значно перевищує середні показники по Україні.

5. До найнебезпечніших речовин, які $є$ фактором ризику розвитку БА в Одеському регіоні, належать такі специфічні забруднювачі як формальдегід, фенол, сажа та сірководень, концентрації яких у повітрі протягом багатьох років перевищують гранично допустимі. 
Огляди літератури, оригінальні дослідження, погляд на проблему, ювілеї

Перспективи подальших досліджень. Доцільно більш поглиблено вивчити провокуючі фактори розвитку БА серед дорослого населення Одеського регіону з метою створення методич- них рекомендацій для сімейних лікарів щодо раннього прогнозування розвитку БА, перебігу та розвитку ускладнень.

Конфлікт інтересів відсутній.

\section{ЛІТЕРАТУРА}

1. Наказ Міністерства охорони здоров'я України від 08 жовтня 2013 року № 868 «Уніфікований клінічний протокол первинної, вторинної (спеціалізованої) медичної допомоги Бронхіальна астма» [Електронний ресурс]. - Режим доступу: http://mtd.dec.gov.ua/images/ dodatki/2013_868BA_dor_dit/2013_868_ykpmd_BA_dity. pdf. - Назва з домашньої сторінки Інтернету.

2. Фещенко Ю. І. ІХ Астма-конгрес: новітні методи діагностики, сучасні підходи до терапії, перспективи розвитку / Ю. І. Фещенко // Пульмонологія, алергологія, риноларингологія // Здоров'я України. - 2015. - № 4. C. 14-15.

3. Effects on asthma and respiratory allergy of Climate change and air pollution / Gennaro D'Amato, Carolina Vitale, Annamaria De Martino [et al.] // Multidiscip Respir Med. - 2015. - Vol. 10. - P. 39.

4. Регіональна доповідь про стан навколишнього природного середовища в Одеській області у 2016 році / Одеська облдержадміністрація, Департамент екології та природних ресурсів. - Одеса, 2016. - С. 16-20.

\section{REFERENCES}

1. Nakaz Ministerstva okhorony zdorovia Ukrainy 08 zhovtnia 2013 roku nomer 868 "Unifikovanyi klinichnyi protokol pervynnoi, vtorynnoi (spetsializovanoi) medychnoi dopomohy Bronkhialna astma" [Order of the Ministry of Health of Ukraine dated October 08, 2013, No. 868 "Unified clinical protocol of primary, secondary (specialized) medical care Bronchial asthma"]. Retrieved from: http://mtd.dec. gov.ua/images/dodatki/2013_868BA_dor_dit/2013_868_ ykpmd_BA_dity.pdf. [in Ukrainian].

2. Feshchenko, Yu.I. (2015). IX Astma-konhres: novitni metody diahnostyky, suchasni pidkhody do terapii, perspektyvy rozvytku [IX Asthma Congress: Newest Methods of Diagnosis, Modern Approaches to Therapy, Prospects for Development]. Pulmonolohiia, alerholohiia, rynolarynholohiia. Zdorovia Ukraiiny - Pulmonology, Allergology, Rhinolaryngology. Health of Ukraine, 4, 14-15 [in Ukrainian].

3. D'Amato G., Vitale C., De Martino A., Viegi G., Lanza M., Molino A. et. al. (2015). Effects on asthma and respiratory allergy of Climate change and air pollution. Multidiscip. Respir. Med., 10, 39.

4. Rehionalna dopovid pro stan navkolyshnoho pryrodnoho seredovyshcha v Odeskii oblasti u 2016 rotsi [Comparative data on the prevalence of respiratory diseases and medical care for patients with pulmonologic and allergic diseases in Ukraine for 2010-2016]. (2016). Odeska obl. derzh. administratsiia, Departament ekolohii ta pryrodnykh resursiv - Odesa Regional State Administration, Department of Ecology and Natural Resources [in Ukrainian].
5. Порівняльні дані про розповсюдженість хвороб органів дихання і медичну допомогу хворим на хвороби пульмонологічного та алергологічного профілю в Україні за 2010-2016 рр. - К. : Ліра, 2017. - 48 с.

6. Огляд стану забруднення навколишнього природного середовища на території України за даними спостережень гідрометеорологічних організацій у 2016 році. К. : Центральна геофізична обсерваторія, 2017. - 47 с.

7. Національна доповідь про стан навколишнього природного середовища в Україні у 2015 році. - К. : Міністерство екології та природних ресурсів України, ФОП Грінь Д. С., 2017. - 308 с.

8. Relationship between the concentration of formaldehyde in the air and asthma in children: a meta-analysis / Yingshui Yao, Wei Liang, Lijun Zhu [et al.] // Int. J. Clin. Exp. Med. - 2015. - Vol. 8 (6). - P. 8358-8362.

9. Acid fog: Effects on respiratory function and symptoms in healthy and asthmatic volunteers / J. D. Hackney, W. S. Linn, E. L. Avol // Environmental Health Perspectives. - 1989. - Vol. 79. - P. 159-162.
5. Porivnialni dani pro rozpovsiudzhenist khvorob orhaniv dykhannia i medychnu dopomohu khvorym na khvoroby pulmonolohichnoho ta alerholohichnoho profiliu $v$ Ukraini za 2010-2016 roky [Comparative data on the prevalence of respiratory diseases and medical care for patients with pulmonologic and allergic diseases in Ukraine for 20102016]. (2017). Kyiv: Lira [in Ukrainian].

6. Ohliad stanu zabrudnennia navkolyshnoho pryrodnoho seredovyshcha na terytorii Ukrainy za danymy sposterezhen hidrometeorolohichnykh orhanizatsii u 2016 rotsi [Review of the state of environmental pollution in the territory of Ukraine according to observations of hydrometeorological organizations in 2016]. (2017). Kyiv: Tsentralna heofizychna observatorii [in Ukrainian].

7. Natsionalna dopovid pro stan navkolyshnoho pryrodnoho seredovyshcha v Ukraini u 2015 rotsi [National report on the state of the environment in Ukraine in 2015]. (2017). Kyiv: Ministerstvo ekolohii ta pryrodnykh resursiv Ukrainy. FOP Hrin D.S. [in Ukrainian].

8. Yao Y., Liang W., Zhu L., Duan Y., Jin Y., He L. (2015). Relationship between the concentration of formaldehyde in the air and asthma in children: a meta-analysis. Int. J. Clin. Exp. Med., 8 (6), 8358-8362.

9. Hackney J.D., Linn W.S., \& Avol E.L. (1989). Acid fog: Effects on respiratory function and symptoms in healthy and asthmatic volunteers. Environmental Health Perspectives., $79,159-162$. 


\section{Огляди літератури, оригінальні дослідження, погляд на проблему, ювілеї}

\section{АНАЛИЗ РАСПРОСТРАНЕННОСТИ И ЗАБОЛЕВАЕМОСТИ БРОНХИАЛЬНОЙ АСТМОЙ И СОСТОЯНИЯ АТМОСФЕРНОГО ВОЗДУХА В ОДЕССКОМ РЕГИОНЕ В ТЕЧЕНИЕ 2006-2016 ГОДОВ

\author{
○О. И. Сандул', В. И. Величко1, Г. А. Данильчук', И. А. Брашко²
} \\ Одесский национальный медицинский университет ${ }^{1}$ Департамент здравоохранения Одесской областной государственной администрации 2}

РЕзюМЕ. Целью нашего исследования было провести анализ распространенности и заболеваемости бронхиальной астмой среди взрослого населения в Одесском регионе в течение 2006-2016 годов и оценить эпидемиологическую ситуацию по соотношению к техногенной нагрузке атмосферного воздуха основными промышленными загрязнителями.

Материал и методы. Проведен ретроспективный анализ отчетной документации Департамента здравоохранения Одесской областной государственной администрации по распространенности бронхиальной астмы среди взрослого населения Одесского региона за период с 2006 по 2016 год. Также были проанализированы данные годовых отчетов Министерства экологии и природных ресурсов Украины о состоянии окружающей природной среды за 2010-2016 годы и проведен анализ техногенной нагрузки атмосферного воздуха основными промышленными загрязнителями в Одесском регионе за этот период. Уровни показателей заболеваемости и распространенности бронхиальной астмы соотносились с динамикой объемов техногенного загрязнения атмосферного воздуха.

Результаты. За проанализированный период в Одесском регионе показатели распространенности и заболеваемости бронхиальной астмой среди взрослого населения значительно превысили средние показатели по Украине. При этом в атмосферном воздухе отмечалось превышение предельно допустимых концентраций ряда специфических техногенных загрязнителей, способных оказывать негативное влияние на состояние дыхательной системы и способствовать развитию бронхиальной астмы.

Среди наиболее опасных загрязнителей атмосферного воздуха следует отметить такие вредные вещества как формальдегид, фенол, сажу и сероводород, концентрации которых в Одесском регионе в течение многих лет превышают предельно допустимые. Это подтверждает и факт того, что уровень распространенности и заболеваемости бронхиальной астмой выше в городах региона, где сосредоточены важные промышленные объекты, чем в сельской местности. Уровни показателей заболеваемости бронхиальной астмой соотносились с динамикой объемов загрязнения атмосферного воздуха. Так, увеличение объемов выбросов техногенных загрязнителей совпадали по времени с ростом заболеваемости бронхиальной астмой в регионе.

Выводы. Прослеживается четкая взаимосвязь между динамикой заболеваемости бронхиальной астмой и уровнем техногенной нагрузки атмосферного воздуха основными промышленными загрязнителями, так как пики загрязнения и заболеваемости совпадают во времени.

КЛЮЧЕВЫЕ СЛОВА: бронхиальная астма; распространенность; заболеваемость; техногенные загрязнители; атмосферный воздух.

\section{ANALYSIS OF THE PREVALENCE AND INCIDENCE OF BRONCHIAL ASTHMA AND THE STATE OF ATMOSPHERIC AIR IN THE ODESA REGION DURING 2006-2016

\author{
๑O. I. Sandul', V. I. Velichko', G. O. Danilchuk', I. O. Brasko² \\ Odesa National Medical University' \\ Department of Health of Odesa Regional State Administration ${ }^{2}$
}

SUMMARY. The aim of our study was to analyze the prevalence and incidence of bronchial asthma among adults in the Odesa region during 2006-2016 and assess the epidemiological situation by the ratio to the anthropogenic air pollutants by the main industrial pollutants.

Material and Methods. A retrospective analysis of the reporting documentation of the Department of Health of the Odesa Regional State Administration on the prevalence of bronchial asthma among the adult population of the Odesa region during the period from 2006 to 2016 was conducted. The data of the annual reports of the Ministry of Ecology and Natural Resources of Ukraine on the state of the environment since 2010 to 2016 were analyzed and the analysis of industrial loads of atmospheric air by the main anthropogenic pollutants in the Odesa region during this period was implemented. The levels of the prevalence and incidence of bronchial asthma were correlated with the dynamics of the volumes of anthropogenic air pollution.

Results. The prevalence and incidence of bronchial asthma among the adult population significantly exceeded the average for Ukraine during our study. At the same time, exceeding the permissible concentrations of a number of specific man-made pollutants were observed, which could have a negative effect on the state of the respiratory system and contribute to the development of bronchial asthma. 
Огляди літератури, оригінальні дослідження, погляд на проблему, ювілеї

Among the most dangerous air pollutants cannot but mention such harmful substances as formaldehyde, phenol, carbon black and sulfuretted hydrogen, the concentrations of which in the Odesa region for many years exceed the maximum permissible concentrations. This is confirmed by the fact that the prevalence and incidence of bronchial asthma is higher in the cities of the region where important industrial facilities are concentrated than in rural areas. Incidence of bronchial asthma were correlated with the dynamics of the volumes of atmospheric air pollution. Thus, the increase in emissions of anthropogenic pollutants coincided with the increase in the incidence of bronchial asthma in the region.

Conclusions. There is a clear correlation between the dynamics of the incidence of bronchial asthma and the level of anthropogenic air loads by the main industrial pollutants, since the peaks of pollution and incidence coincide in time.

KEY WORDS: bronchial asthma; prevalence; incidence; air pollutants; atmospheric air. 